RESEARCH ARTICLES

PALEOCEANOGRAPHY

\section{Onset of Mediterranean outflow into the North Atlantic}

\author{
F. Javier Hernández-Molina, ${ }^{1 *}$ Dorrik A. V. Stow, ${ }^{2}$ Carlos A. Alvarez-Zarikian, ${ }^{3}$ \\ Gary Acton, ${ }^{4}$ André Bahr, ${ }^{5}$ Barbara Balestra, ${ }^{6}$ Emmanuelle Ducassou, ${ }^{7}$ Roger Flood, ${ }^{8}$ \\ José-Abel Flores, ${ }^{9}$ Satoshi Furota, ${ }^{10}$ Patrick Grunert, ${ }^{11}$ David Hodell, ${ }^{12}$ \\ Francisco Jimenez-Espejo, ${ }^{13}$ Jin Kyoung Kim, ${ }^{14}$ Lawrence Krissek, ${ }^{15}$ \\ Junichiro Kuroda, ${ }^{16}$ Baohua Li, $^{17}$ Estefania Llave, ${ }^{18}$ Johanna Lofi, ${ }^{19}$ Lucas Lourens, ${ }^{20}$ \\ Madeline Miller, ${ }^{21}$ Futoshi Nanayama, ${ }^{22}$ Naohisa Nishida, ${ }^{22}$ Carl Richter, ${ }^{23}$ \\ Cristina Roque, ${ }^{24}$ Hélder Pereira, ${ }^{25}$ Maria Fernanda Sanchez Goñi, ${ }^{26}$ \\ Francisco J. Sierro, ${ }^{9}$ Arun Deo Singh, ${ }^{27}$ Craig Sloss, ${ }^{28}$ Yasuhiro Takashimizu, ${ }^{29}$ \\ Alexandrina Tzanova, ${ }^{30}$ Antje Voelker, ${ }^{24}$ Trevor Williams, ${ }^{31}$ Chuang Xuan ${ }^{32}$
}

Sediments cored along the southwestern Iberian margin during Integrated Ocean Drilling Program Expedition 339 provide constraints on Mediterranean Outflow Water (MOW) circulation patterns from the Pliocene epoch to the present day. After the Strait of Gibraltar opened (5.33 million years ago), a limited volume of MOW entered the Atlantic. Depositional hiatuses indicate erosion by bottom currents related to higher volumes of MOW circulating into the North Atlantic, beginning in the late Pliocene. The hiatuses coincide with regional tectonic events and changes in global thermohaline circulation (THC). This suggests that MOW influenced Atlantic Meridional Overturning Circulation (AMOC), THC, and climatic shifts by contributing a component of warm, saline water to northern latitudes while in turn being influenced by plate tectonics.

I ectonic activity exerts primary control on sedimentation along continental margins and on seafloor morphology, whereby it also influences bottom current flow pathways. Sea level variation and climate also influence sedimentation along continental margins. Plate tectonic configuration plays an important role in climate (1), although uncertainty persists concerning the specific cause-effect relationships and their relative importance on a temporal scale. From the late Miocene to the Pleistocene, Earth experienced major plate tectonic, climatic, and oceanographic shifts that, along with orbital variation, contributed to present-day global climate dynamics (2). These events include the closure and reopening of gateways between the Atlantic and Mediterranean basins [ 5.55 to 5.33 million years ago (Ma) (3)], the closure of the deep Central American Seaway (CAS) [4.5 to $3.0 \mathrm{Ma}(4)$ ] and the Indonesian Seaway [ 4 Ma (2)], and the onset of Northern Hemisphere glacial (NHG) cycles in the late Pliocene (5). Neogene sedimentary sections also record Pliocene warming trends that culminate in the mid-Pliocene warm period [3.3 to 3.0 Ma (6)], the Panama seaway closure [ $\sim 3.0$ to $2.7 \mathrm{Ma}(7)]$, and NHG intensification around 2.72 Ma [Marine Isotope Stage (MIS) G6 (5)]. During this period, increases in evaporation and precipitation facilitated ice sheet formation, higher albedo, and increased Atlantic Meridional Overturning Circulation (AMOC) $(4,8)$. The global transition to Quaternary glacial cycles at $2.7 \mathrm{Ma}(5,8)$, a predicted major glaciation at
$2.15 \mathrm{Ma}(9)$, and the recent mid-Pleistocene transition at $\sim 0.9$ to $0.7 \mathrm{Ma} \mathrm{(10)}$ also relate to the establishment and stabilization of present-day ocean circulation patterns.

Changes in the Mediterranean Outflow Water (MOW) co-occurred with some of these shifts in global ocean circulation and climate, but the exact timing of MOW evolution with respect to major climate events remains unclear. The Strait of Gibraltar strongly influences MediterraneanAtlantic water mass exchange, contributing warm and highly saline MOW to the Atlantic Ocean. MOW currently enters the Strait of Gibraltar with a density of $29.12 \mathrm{~kg} / \mathrm{m}^{3}(8)$; its density is $27.7 \mathrm{~kg} / \mathrm{m}^{3}$ in the Gulf of Cadiz and off Brittany $(11,12)$ and $27.4 \mathrm{~kg} / \mathrm{m}^{3}$ further afield along the Rockall Plateau of the northeastern Atlantic extension (12). MOW input thus enhances North Atlantic density and helps drive thermohaline convection. Estimates suggest that without MOW, the AMOC would decline by $\sim 15 \%$ and North Atlantic sea surface temperatures would fall by up to $1^{\circ} \mathrm{C}(8)$. The Gulf of Cadiz and the western margin of Portugal record critical aspects of MOW development as well as the interaction between MOW and AMOC. Upon exiting the Strait of Gibraltar, MOW consists of relatively warm and highly saline water (Fig. 1) that settles into an intermediate bottom current within the mid-slope region, between 400 and $1400 \mathrm{~m}$ water depth, at an overflow rate of $0.67 \pm 0.28 \mathrm{~Sv}$ (11). This region lies beneath Atlantic Water (AW) inflow but rafts above North Atlantic Deep Water (NADW).

This paper interprets the sequence of events that established an important MOW contribution to North Atlantic thermohaline dynamics, and makes inferences concerning how these dynamics relate to Neogene and Quaternary climatic and tectonic events. Our study combines geophysical and drill core data acquired along the southwestern Iberian margin during Integrated Ocean Drilling Program (IODP) Expedition 339 aboard the research vessel JOIDES Resolution (Fig. 1).

The southwestern Iberian margin is located near the Azores-Gibraltar Fracture Zone, which is a section of the convergent plate boundary between Eurasia (Iberia subplate) and Africa (Nubia subplate). The plates currently converge at a rate of $\sim 4$ to $5 \mathrm{~mm} /$ year in a WNW-ESE direction. Counterclockwise rotation is accommodated by a series of thrusts and dextral strike-slip faults $(13,14)$ active since at least 1.8 Ma. Starting in the late Miocene, the southwestern Iberian margin evolved by oblique convergence between the Iberia and Nubia subplates (13) and westward rollback subduction of an oceanic lithosphere slab beneath the Gibraltar Arc, both of which facilitate development of the Cadiz Allochthonous Unit (CAU) (15) or accretionary

Department of Earth Sciences, Royal Holloway, University of London, Egham, Surrey TW20 OEX, UK. ${ }^{2}$ Institute of Petroleum Engineering, Heriot-Watt University, Edinburgh EH14 4AS, Scotland, UK. International Ocean Discovery Program, Department of Oceanography, Texas A\&M University, College Station, TX 77845, USA. ${ }^{4}$ Department of Geography and Geology, Sam Houston State University, Huntsville, TX 77341 USA. Institute of Geosciences, University of Frankfurt, 60438 Frankfurt, Germany. ${ }^{6}$ Institute of Marine Sciences, University of California, Santa Cruz, CA 95064, USA. ${ }^{7} E P O C$, Université de Bordeaux, 33615 Pessac Cedex, France. ${ }^{8}$ School of Marine and Atmospheric Sciences, Stony Brook University, Stony Brook, NY 11794, USA. ${ }^{9}$ Departamento de Geología, Universidad de Salamanca, 3008 Salamanca, Spain. ${ }^{10}$ Department of Natural History Sciences, Hokkaido University, N10W8, Kita-ku, Sapporo 060-0810, Japan. ${ }^{11}$ Institute for Earth Sciences, University of Graz, A-8010 Graz, Austria. ${ }^{12}$ Godwin Laboratory for Palaeoclimate Research, University of Cambridge, Cambridge CB2 3EQ, UK. ${ }^{13}$ Department of Biogeochemistry, JAMSTEC, 237-0061 Yokosuka, Japan. ${ }^{14}$ Korea Institute of Ocean Science \& Technology, Ansan 426-744, Korea. ${ }^{15}$ School of Earth Sciences, Ohio State University, Columbus, OH 43210, USA ${ }^{16}$ Institute for Frontier Research on Earth Evolution (IFREE), JAMSTEC, 2-15 Natsushima-Cho, Yokosuka-city, Kanagawa 237-0061, Japan. ${ }^{17}$ Department of Micropalaeontology, Nanjing Institute of Geology and Palaeontology, Chinese Academy of Sciences, Nanjing 210008, P.R. China. ${ }^{18}$ Instituto Geológico y Minero de España, Ríos Rosas 23, 28003 Madrid, Spain. ${ }^{19}$ Géosciences Montpellier, Université Montpellier II, 34090 Montpellier, France, and Department of Geology, University of Leicester, Leicester LE1 7RH, UK. ${ }^{20}$ Institute of Earth Sciences, Utrecht University, 3584 CD Utrecht, Netherlands.

${ }^{21}$ Department of Mechanical Engineering, California Institute of Technology, Pasadena, CA 91125, USA. ${ }^{22}$ Institute of Geology and Geoinformation, Geological Survey of Japan (AIST), Ibaraki 305-8567, Japan. ${ }^{23}$ School of Geosciences, University of Louisiana, Lafayette, LA 70504, USA. ${ }^{24}$ Divisão de Geologia e Georecursos Marinhos, IPMA, 1749-077 Lisboa, Portugal. ${ }^{25}$ Grupo de Biologia e Geologia, Escola Secundária de Loulé, 8100-740 Loulé, Portugal. ${ }^{26}$ École Pratique des Hautes Etudes, EPOC, Université de Bordeaux, 33615 Pessac, France. ${ }^{27}$ Department of Geology, Banaras Hindu University, Varanasi 221005, India. ${ }^{28}$ School of Earth, Environmental and Biological Sciences, Queensland University of Technology, Brisbane, Queensland 4001, Australia. ${ }^{29}$ Department of Geology, Faculty of Education, Niigata University, Niigata 950-2181, Japan. ${ }^{30}$ Department of Geological Sciences, Brown University, Providence, RI 02912, USA. ${ }^{31}$ Lamont-Doherty Earth Observatory, Columbia University, Palisades, NY 10964, USA. ${ }^{32}$ Ocean and Earth Science, National Oceanography Centre Southampton, University of Southampton, Waterfront Campus, Southampton SO14 3ZH, UK.

*Corresponding author. E-mail: javier.hernandez-molina@rhul. ac.uk 
wedge (16). Distinct periods of crustal deformation, fault reactivation, and halokinesis related to plate motion have contributed to the tectonostratigraphic evolution of the area (13). Sediments within the Gulf of Cadiz record the opening of the Strait of Gibraltar, and event that initiated MOW intrusion into the North Atlantic. Subsequent intensification of MOW established along-slope depositional systems and generated an extensive contourite depositional system (CDS) (17) that provides a sedimentary record of the paleoceanographic events analyzed and interpreted here.

\section{Seismic records and drill cores as tracers of MOW dynamics from the late Miocene to the present}

Major regional discontinuities appear as highamplitude seismic reflections within late Miocene to present-day sediments around the Gulf of Cadiz (Fig. 2 and fig. S1). These discontinuities provide a record of MOW circulation relative to coeval tectonic and climatic events. Pliocene deposits appear in seismic profiles as sheeted drifts overlying a weakly reflecting Miocene unit that progrades downslope (Fig. 2 and fig. S1). The late Pliocene to lower Quaternary section provides a record of substantial synsedimentary deformation associated with two discontinuities that define a major truncation surfaces (fig. S2). Quaternary deposits are distinguished by highamplitude seismic reflections and show clear upslope progradation.

Closure of the Strait of Gibraltar and the BeticRharb corridors during the Messinian Salinity Crisis (5.56 to $5.33 \mathrm{Ma}$ ) prevented MediterraneanAtlantic water exchange (3). Exchange resembling present-day flows through these channels is thought to have begun with the opening of the Strait of Gibraltar and the related onset of the latest Miocene flooding at $\sim 5.33 \mathrm{Ma}$ (3). Widespread discontinuities evident in seismic records and pervasive hiatuses evident in Expedition 339 drill cores suggest four major phases of MOW evolution after the opening of the Strait of Gibraltar (Fig. 2, Fig. 3, and fig. S1).

The primary phase of downslope activity occurred during the early Pliocene ( 5.2 to $4.5 \mathrm{Ma}$ ) as downslope mass transport deposits (slumps and debrites) and turbidites developed in response to widespread tectonic activity. These deposits overlie a regional discontinuity (Fig. 2 and fig. S1) above the late Miocene hemipelagic deposits (Fig. 4 and fig. S3). Drill core results suggest only a limited degree of contourite deposition beginning in the Pliocene. The opening of the Strait of Gibraltar caused slope instability (3), leading to gravitational-collapse breccia deposits (18).

The second phase began with the onset of limited MOW circulation between 4.5 and $3.5 \mathrm{Ma}$. Persistent sequences of contourite facies from 4.5 to 4.2 Ma show clear evidence of initial MOW circulation into the Gulf of Cadiz and subsequent interaction between MOW and the North Atlantic.

The third phase is defined by enhanced MOW circulation from 3.2 to $2.1 \mathrm{Ma}$. Two major hiatuses, at 3.2 to $3.0 \mathrm{Ma}$ and at 2.4 to $2.1 \mathrm{Ma}$, indicate erosion by bottom currents and enhanced interaction between MOW and the North Atlantic. Major and uninterrupted contourite deposition occurs

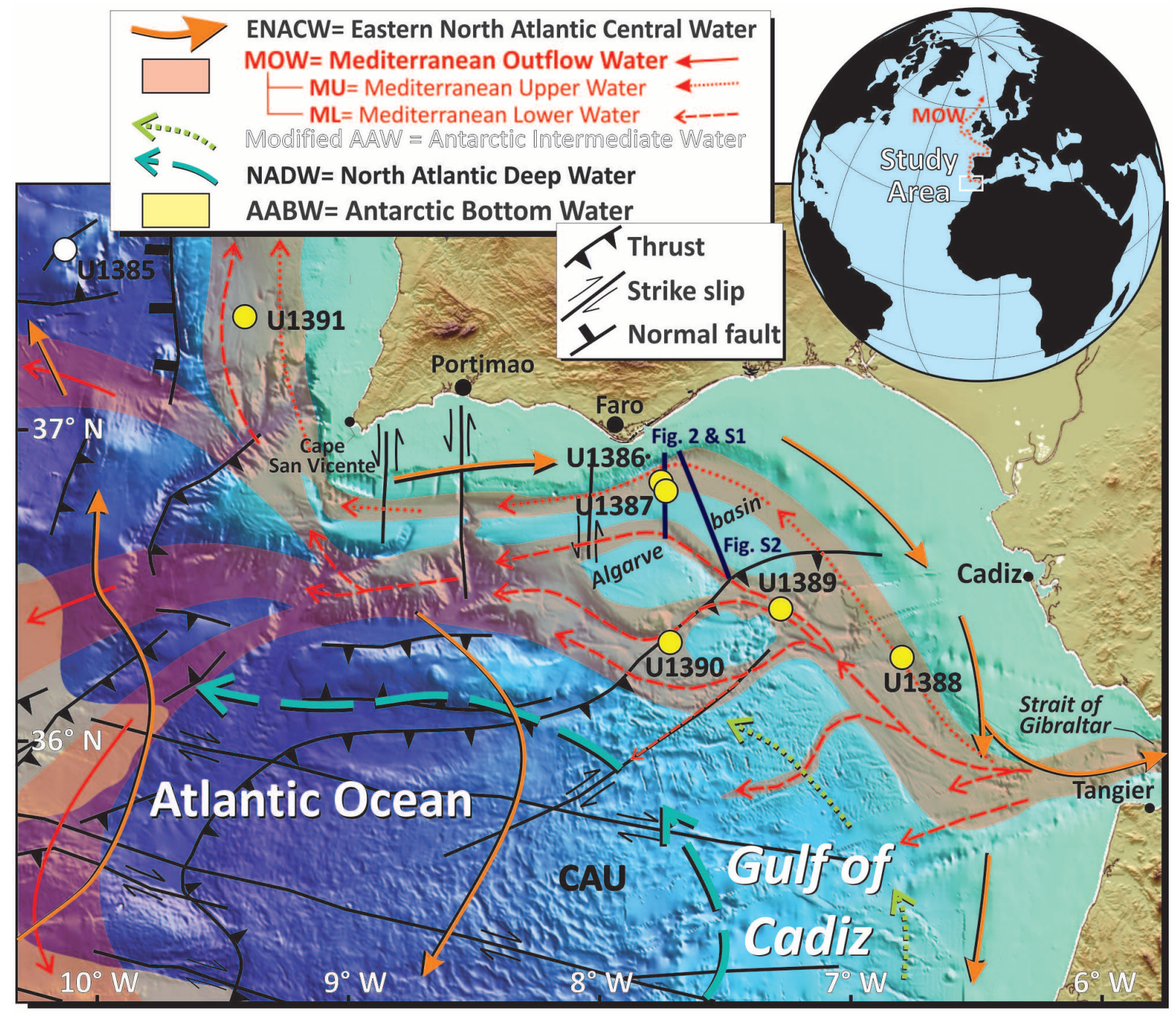

Fig. 1. Regional water masses, major tectonic features, and Gulf of Cadiz CDS site locations sampled during IODP Expedition 339. 
only above the upper Pliocene hiatus at 3.2 to 3.0 Ma, where dolostones and debrite deposits occur (Figs. 2 and 4). Interbedded turbidites and contourites are also common in the upper Pliocene section. Dolostone deposits are closely linked to the aforementioned hiatus, wherein they may have precipitated as a result of shallow diagenetic processes (Fig. 2). That hiatus is the first major event evident within the sedimentary stacking pattern throughout the northern Gulf of Cadiz slope (19) and within the Strait of Gibraltar (18). Quaternary successions show a much more pronounced phase of contourite deposition and drift development. These deposits consist of sandy and muddy contourites with periodic turbidite intercalations. They also show a considerable phase of downslope sedimentation at $\sim 2 \mathrm{Ma}$. A regional hiatus, which occurs within the Quaternary section at $\sim 2.4$ to $2.1 \mathrm{Ma}$, is also associated with dolostones and debrite deposits (Figs. 2 and 4). This hiatus appears as an important discontinuity within drift near the base of the Quaternary. It records a period of tectonic instability coeval with erosion by bottom currents and substantially higher volumes of MOW input into the North Atlantic relative to flow onset at 4.5 to 4.2 Ma.

The final phase, beginning with the establishment of present-day circulation at $2.1 \mathrm{Ma}$ and continuing to this day, is evident from increased sedimentation rates and rapid contourite development. A younger major regional discontinuity with local erosion is clearly evident in the seismic records (Fig. 2 and fig. S1) and is attributed to the midPleistocene transition $(17,20)$, with a tentative age of $0.9 \mathrm{Ma}$ (17). A pronounced change in the drift sedimentary stacking pattern appears at this time horizon as enhanced upslope progradation and mounded morphology, indicating an intensification of MOW $(17,20)$. A specific hiatus or condensed section, however, is not found in all of the drill core material at the 0.9 to $0.7 \mathrm{Ma}$ time horizon (Fig. 3). Ongoing analysis seeks to further constrain the exact age and duration of this discontinuity.

Hiatuses, mass transport deposits (debrites, slumps), and tectonic events occurring at the end of the Miocene (3), 3.2 to $3.0 \mathrm{Ma}(19,21), 2.4$ to $2.0 \mathrm{Ma}$ (13), or $\sim 0.9 \mathrm{Ma}$ (17) around the Gulf of Cadiz appear to coincide with major climatic shifts during this period. Tectonic activity has been a key factor controlling seafloor morphology,

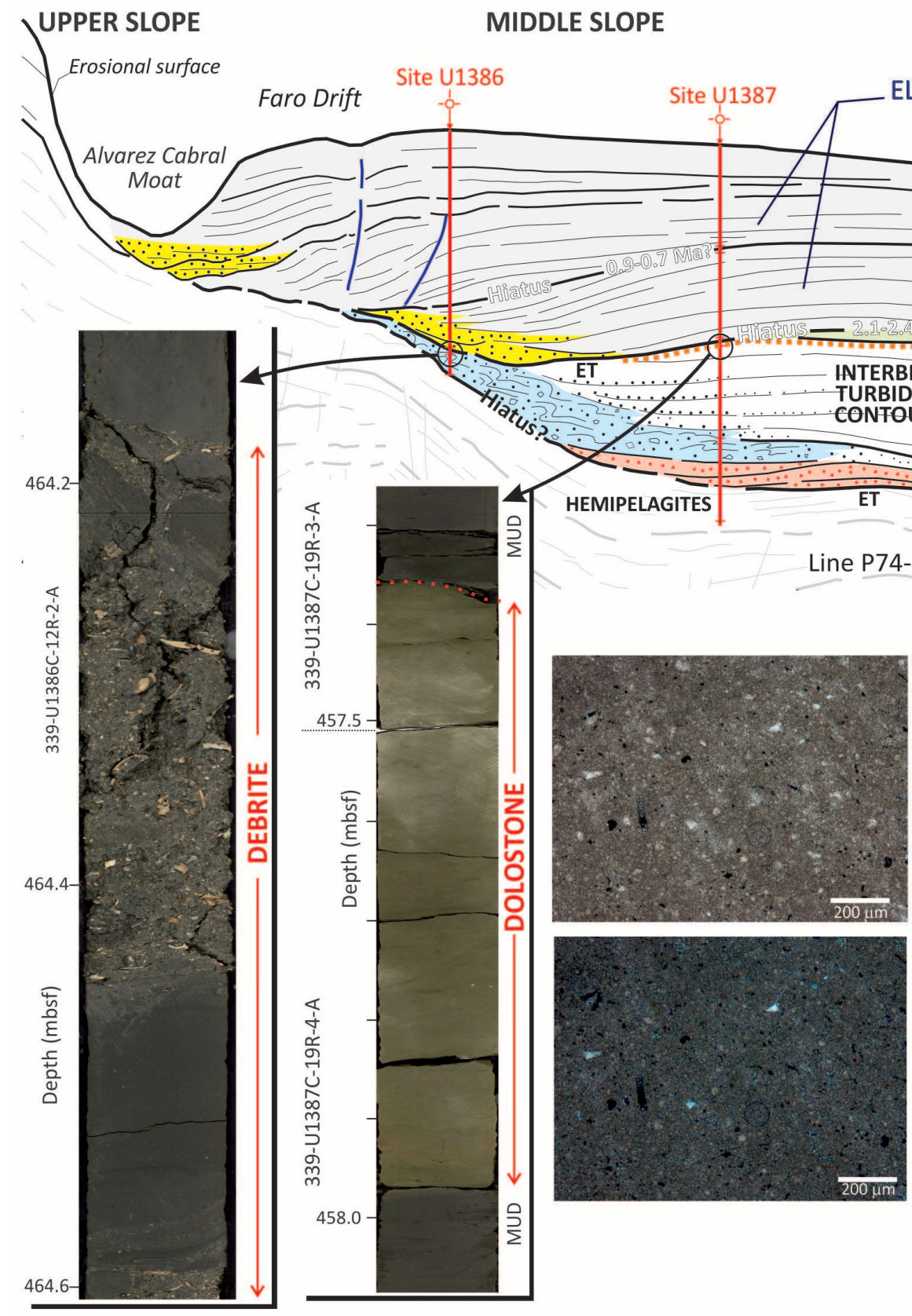

ELONGATED, MOUNDED \& SEPARATED DRIFT

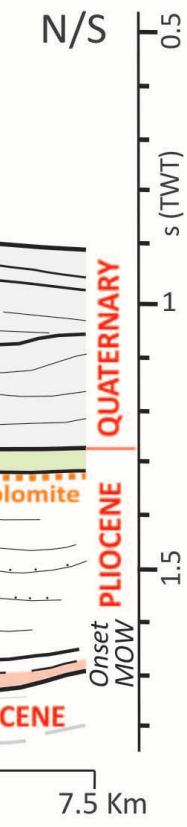

\section{ET $=$ Erosional truncation}
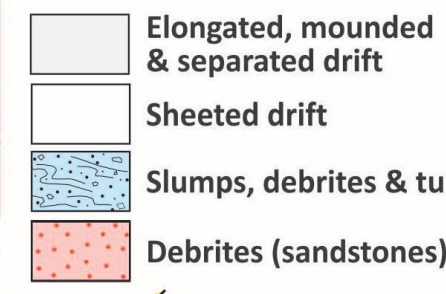
\& separated drift

Sheeted drift

Slumps, debrites \& turbidites

Debrites (sandstones)

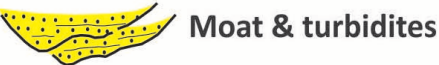

Fig. 2. Stratigraphic section showing major sedimentary stacking patterns from Pliocene sheeted drift deposits to Quaternary separated drift deposits. Core samples of a debrite (left) and dolostone (right) collected directly beneath the hiatuses are also shown (mbsf, meters below seafloor). Planepolarized (upper) and cross-polarized (lower) light photomicrographs of dolostone samples show composition of almost pure micritic dolomite. 
which in turn influences MOW flow pathways and, by extension, deep-water sedimentation. The stratigraphic events thus reflect changes in the Iberia-Nubia subplate kinematics during the Pliocene and Quaternary, which established the present-day transpressional regime. Deformation of the CAU, which initially emplaced in the Algarve basin (fig. S2) in the late Miocene, occurred with reactivation of blind thrusts during the Pliocene and Quaternary. The CAU could therefore record tectonic episodes associated with plate reorganization. Shifts in the Africa-Eurasia plate trajectory after the Messinian Salinity Crisis contributed to the deepening of the gateway (13). The NW-SE to WNW-ESE shift in convergence direction $(13,22)$ coincides with tectonic events between 3.2 and 2.0 Ma. A hiatus previously described from IODP Expedition 339 core records reflects these events, as do other hiatuses identified near the Strait of Gibraltar (23), in the Alboran Sea (24), and in the eastern Atlantic between Gibraltar and the equator (25). The shift in plate convergence direction for the southwestern Iberian margin coincides with a decline in westward migration and thrusting activity for the accretionary wedge. Reactivated blind thrusts accommodated shortening and minor sedimentary accretion (16). At $\sim 1.8 \mathrm{Ma}$, the oblique convergence between the Iberia and Nubia subplates reactivates WNW-ESE dextral strike-slip faults as well as shallower WNW-directed thrusts (14).

\section{Global implications}

The spatial distribution of these hiatuses can help to refine our understanding of MOW development and its overall effect on thermohaline circulation (THC) and deep-water sedimentation. The interpreted sequence of events is summarized in Fig. 5 .

Lower Pliocene sedimentary deposits show no clear evidence of MOW input into the Atlantic prior to $4.5 \mathrm{Ma}$. This time constraint indicates a lag between the full opening of the Strait of Gibraltar ( 5.33 Ma) and the establishment of

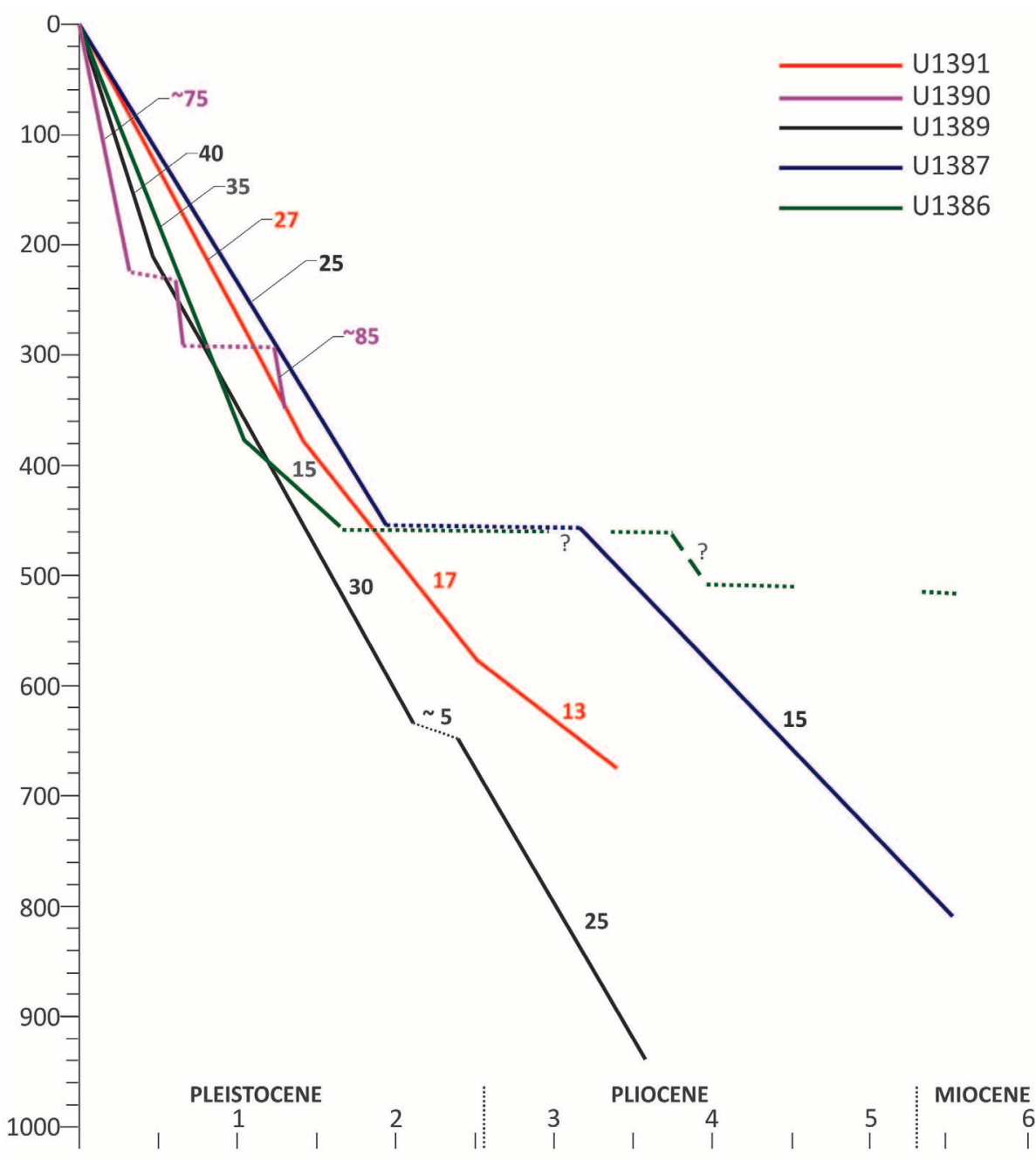

Fig. 3. Age curves and sedimentation rates for sites sampled during IODP Expedition 339. Ages are based on biostratigraphic and magnetostratigraphic dating. These methods identify depositional hiatuses and boundaries between stratigraphic periods and enable the estimation of sedimentary accumulation rates. consistent MOW interaction with the North Atlantic (fig. S4). Similarities in the densities of Mediterranean seawater and Eastern North Atlantic Central Water in the beginning of the early Pliocene (8) may have contributed to this lag. By the early Pliocene, Antarctic Bottom Water (AABW) flowed northward and extended into the North Atlantic with greater intensity. This intensification coincided with a weaker AMOC, especially during glacial stages (25).

At $\sim 4.5 \mathrm{Ma}$, MOW began to circulate into the North Atlantic as an intermediate and deep-water circulation (6). Some authors have reported an additional MOW intensification stage at $\sim 3.8 \mathrm{Ma}$ (23) and $3.5 \mathrm{Ma}$ (12), which coincides with more active circulation in the North Atlantic (12). This second stage demonstrates increasing MOW influence on the North Atlantic and a sedimentary signal shared by MOW- and THC-related phenomena. Notably, the CAS (fig. S4) shoaled by $\sim 4.5$ to $3.5 \mathrm{Ma}$ and began to hinder intermediatelayer circulation. These events blocked NADW flow into the Pacific but enhanced NADW flow into the South Atlantic, initiating the modernday deep-water circulation pattern (6). The modernday pattern delivers warmer, saltier surface water to more northerly locations in the Arctic Ocean, enhancing evaporation, precipitation, and ice sheet formation. These factors established the initial conditions for the mid-Pliocene warm period $(4,8)$. Around this same time ( 4.5 Ma), Labrador Sea Water (LSW) began to circulate as part of the North East Atlantic Deep Water (NEADW) layer (7). This led to increased AMOC circulation between 4.5 and $4.0 \mathrm{Ma}$, as well as increased drift sedimentation in the North Atlantic (2).

Two phases of MOW intensification occurred, one at 3.2 to $3.0 \mathrm{Ma}$ and the other at 2.4 to $2.1 \mathrm{Ma}$. The timing of these events correlates with higheramplitude phases of temperature and insolation oscillations related to the 400,000-year, eccentricitymodulated cycle (6), suggesting a relationship between orbital changes and MOW production.

The first enhanced MOW period began after 3.2 $\mathrm{Ma}$ and coincides with widespread evidence of NEADW circulation. This event contributed to the formation of the present-day NADW (4) through southward deflection of the AABW-NADW contact (south of the Azores). NADW arrival at extreme southerly latitudes around Antarctica in turn cooled the Antarctic water and increased production of $\mathrm{AABW}$, augmenting its flow into the southwest Atlantic (26). A coeval decrease in sedimentary accumulation rates in North Atlantic drift deposits accompanied these events (2). Model experiments indicate that NADW production increased around the time of the final CAS closure at $3 \mathrm{Ma}(6)$. However, the increased strength of the AMOC also suggests additional saline and warm water transport to high latitudes in the North Atlantic. MOW could have supplied this additional saline water component of the AMOC. The present study shows that MOW intensification between 3.2 and 3.0 Ma contributed salt water at intermediate depths to northerly latitudes, thus enhancing AMOC and overall Northern Hemisphere deep-water formation and 
reducing pole-to-equator temperature gradients during the mid-Pliocene warm period. Prior to 3.4 Ma, the density of MOW slightly exceeded the present-day value of $27.8 \mathrm{~kg} / \mathrm{m}^{3}$ (12). Density increased about $1 \mathrm{~kg} / \mathrm{m}^{3}$, maximizing around 3.3 to $3.2 \mathrm{Ma}$ and persisting at this level until $\sim 3.0 \mathrm{Ma}$ (12). The temporal boundary of this density event coincides with the age of the hiatus identified in the Gulf of Cadiz. MOW intensification therefore also contributed salt water at intermediate depths to northerly latitudes, thus enhancing THC, AMOC, and overall Northern Hemisphere deep-water formation.

The second enhanced MOW period (2.4 to $2.1 \mathrm{Ma}$ ) coincided with a sizable stratigraphic gap reported for the northeast Atlantic (24), suggesting synchronous reactivation of the THC and AMOC. This new event would suggest an additional increase in MOW density, which is surprisingly coeval with apparent major glaciation at $2.15 \mathrm{Ma}(9)$.

Present-day MOW dynamics (fig. S4) commenced in the earliest Quaternary and coincided with a shift from long-term global cooling trends (27) marked by the final NHG intensification (4). The shift included a decline in atmospheric $\mathrm{CO}_{2}$ levels, global cooling (27), and a fall in sea level (28). The 41,000-year obliquity cycle replaced the 23,000-year precessional cycle as the primary orbital mechanism influencing climate. This shift is also associated with a progressive increase in the amplitude of Earth's orbital obliquity (4).

While cooler deep waters formed with the subsequent increase in deep ocean stratification, deepwater circulation (and sedimentation), upwelling, and biogenic productivity at low latitudes followed a somewhat asymmetric temporal pattern (29). The present-day NADW configuration deflects the AABW-NADW contact southward during interglacial periods, whereas AABW deflected this contact back in a northward direction during glacial periods $(2,29)$. These dynamics were reinforced by the mid-Pleistocene revolution or transition (0.9 to $0.7 \mathrm{Ma}$ ), which established longer periods for glacial/interglacial cycles. This transition coincided with an increase in the 100,000year cycle amplitude and a major eustatic drop in sea level $(8,28)$, which might relate to the MOW intensification and the formation of the midPleistocene discontinuity $(17,20)$. This increase in MOW coincides with intensification in the AMOC (2). After that transition and subsequent glacial stages, MOW density increased, as it did during the last glaciation when it exceeded $\left(\sim 31.29 \mathrm{~kg} / \mathrm{m}^{3}\right)$ the present-day values $(30)$. Rates of MOW flow were also higher (30), as evident from the morphology of the slope (23).

The aforementioned tectonic events in the Gulf of Cadiz are coeval with other events recorded throughout the Northern Hemisphere (31). The temporal overlap of these events suggests that they relate to overall plate reorganization in the North Atlantic (31) or to widespread mantle activity [e.g., (32)]. More general hypotheses (33) affirm this relationship, further corroborating the role of plate tectonics in modulating climate over a wide range

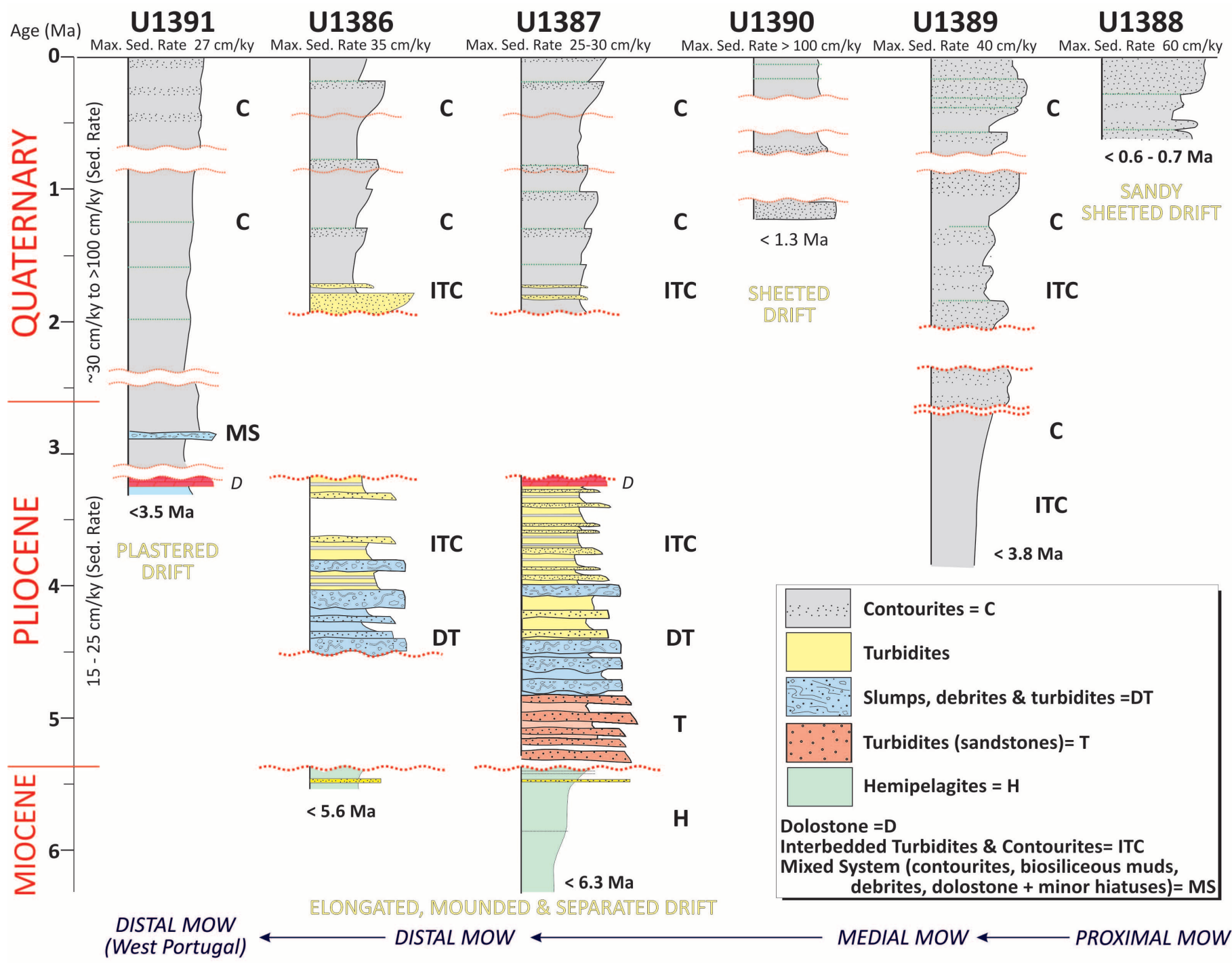

Fig. 4. Lithologic summary of IODP Expedition 339 CDS sample sites, showing major hiatuses. Age model is based on biostratigraphic and magnetostratigraphic data ( $\mathrm{ky}=1000$ years). 
Fig. 5. Neogene and Quaternary evolution of the CDS within the Gulf of Cadiz and the western Portuguese margin. Regional evolution is compared with major events affecting the North Atlantic basin and shifts in global climate $(2,27,28,34)$

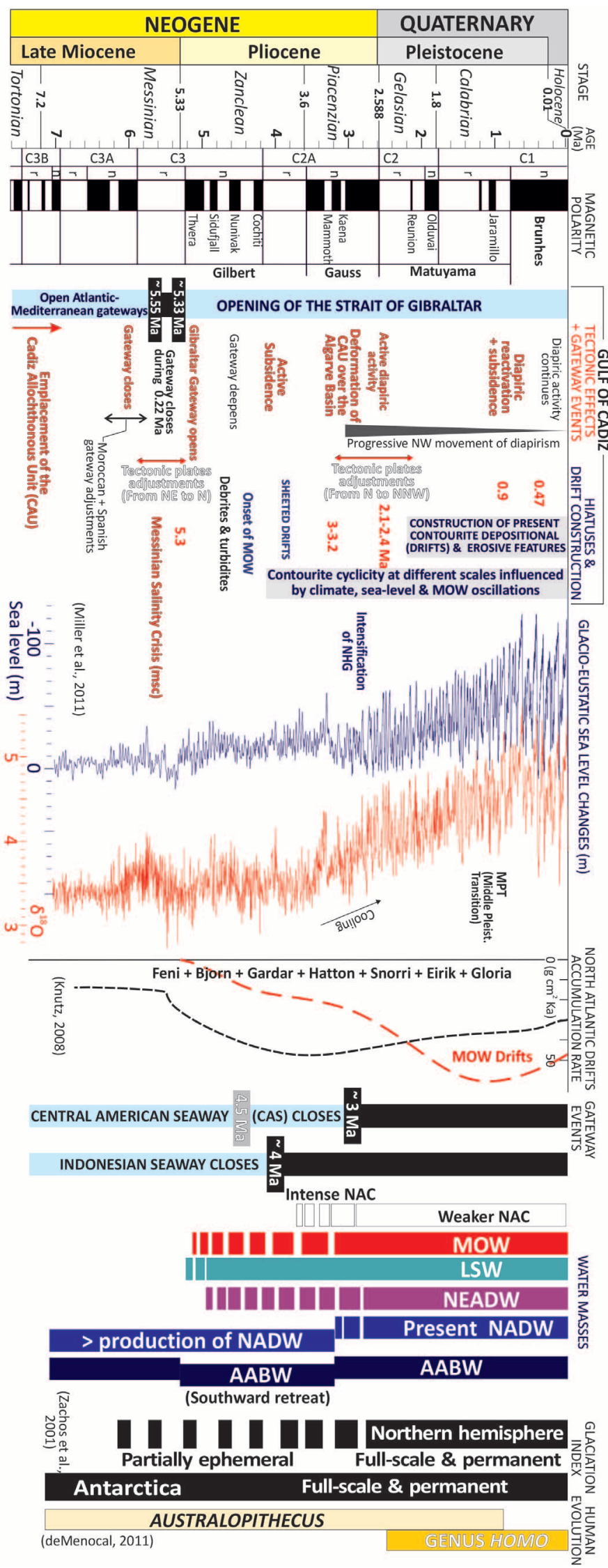

of time scales (1). These should be reconsidered in climatic and sea level reconstruction because, for example, they could explain the discrepancy between the benthic $\delta^{18} \mathrm{O}$ record and the Gibraltar relative sea level that assumes no tectonic changes in the geometry of the Gibraltar Gateway and adjacent areas $(9)$.

\section{Conclusions}

Our results show that the initial MOW circulation into the Atlantic after the opening of the Strait of Gibraltar was relatively weak. Meaningful interaction between MOW and the North Atlantic did not begin until the late Pliocene. The establishment of MOW added relatively salty water at intermediate depths and contributed to enhanced THC and AMOC. The addition of the warm, salty MOW component reduced pole-toequator temperature gradients during the midPliocene warm period (3.2 to $3.0 \mathrm{Ma}$ ), during the early Quaternary (2.4 to $2.0 \mathrm{Ma}$ ), and at 0.9 to $0.7 \mathrm{Ma}$. These climatic events coincide with widespread depositional hiatuses, pronounced changes in the sedimentary stacking pattern, and establishment of the present-day seafloor morphology. Hiatuses and shifts in depositional processes are related to regional tectonic events and margin instability. Similar changes in deep-water sedimentation and tectonics have been described in association with other margins and basins around the same time in both the Northern and Southern hemispheres, demonstrating that the relationship between climatic shifts and plate tectonic events operates over a wide range of time scales. The relationship between climate and plate tectonic events is especially relevant for this geographic locality because of its role as the site of major events in hominid migration and evolution (34).

\section{REFERENCES AND NOTES}

1. W. W. Hay, Geol. Rundsch. 85, 409-437 (1996).

2. P. C. Knutz, Palaeoceanographic significance of contourite drifts. In Contourites: Developments in Sedimentology, vol. 60 M. Rebesco, M. A. Camerlenghi, Eds. (Elsevier, Amsterdam, 2008), pp. 511-535.

3. M. Roveri et al., Mar. Geol. 10.1016/j.margeo.2014.02.002 (2014).

4. G. Bartoli et al., Earth Planet. Sci. Lett. 237, 33-44 (2005).

5. I. Bailey et al., Quat. Sci. Rev. 75, 181-194 (2013)

6. M. A. Maslin, X. S. Li, M.-F. Loutre, A. Berger, Quat. Sci. Rev. 17, 411-426 (1998).

7. K. H. Nisancioglu, M. E. Raymo, P. H. Stone, Paleoceanography 18, 1006 (2003).

8. M. Rogerson, E. J. Rohling, G. R. Bigg, J. Ramirez, Rev. Geophys. 50, RG2003 (2012).

9. E. J. Rohling et al., Nature 508, 477-482 (2014).

10. H. Elderfield et al., Science 337, 704-709 (2012).

11. N. Serra, I. Ambar, D. Boutov, Ocean Sci. 6, 191-209 (2010)

12. N. Khélifi et al., Geology 37, 811-814 (2009).

13. N. Zitellini et al., Earth Planet. Sci. Lett. 280, 13-50 (2009).

14. J. Duarte et al., Mar. Geol. 289, 135-149 (2011).

15. T. Medialdea et al., Mar. Geol. 209, 173-198 (2004).

16. M.-A. Gutscher et al., Geology 30, 1071-1074 (2002).

17. E. Llave et al., in Economic and Paleoceanographic Importance of Contourites, A. Viana, M. Rebesco, Eds. (Geological Society of London Special Publication, 2007) vol. 276, pp. 49-79.

18. M. Esteras et al., Rev. Soc. Geol. Esp. 13, 539-550 (2000). 
19. R. A. Brackenridge, F. J. Hernández-Molina, D. A. V. Stow, E. Llave, Mar. Pet. Geol. 46, 36-50 (2013).

20. C. Roque et al., Mar. Geol. 303-306, 42-62 (2012).

21. J. F. Flinch, P. R. Vail, in Mesozoic and Cenozoic Sequence Stratigraphy of European Basins, SEPM Special Publication Series no. 60, P. C. de Graciansky, J. Hardenbol, T. Jacquin, P. R. Vail, Eds. (Society for Sedimentary Geology, Tulsa, OK, 1998), pp. 199-208.

22. P. Martínez-García, M. Comas, J. I. Soto, L. Lonergan, A. B. Watts, Basin Res. 25, 361-387 (2013).

23. F. J. Hernández-Molina et al., Geology 42, 227-230 (2014).

24. K. Billups, A. C. Ravelo, J. C. Zachos, Paleoceanography 13, 84-95 (1998).

25. R. Stein et al., in North Atlantic Paleoceanography, C. P. Summerhayes, N. J. Shackleton, Eds. (Geological Society, London, 1986), pp. 103-118.

26. M. T. Ledbetter, D. F. Williams, B. B. Ellwood, Nature 272 237-239 (1978)

27. J. Zachos, M. Pagani, L. Sloan, E. Thomas, K. Billups, Science 292, 686-693 (2001)
28. K. G. Miller, G. Mountain, J. Wright, J. Browning, Oceanography 24, 40-53 (2011)

29. G. S. Dwyer et al., Science 270, 1347-1351 (1995).

30. M. Rogerson, G. R. Bigg, E. J. Rohling, J. Ramirez, Clim. Dyn. 39, 589-598 (2012).

31. S. Cloetingh, F. M. Gradstein, H. Kooi, A. C. Grant, M. Kaminski, J. Geol. Soc. London 147, 495-506 (1990).

32. N. White, B. Lovell, Nature 387, 888-891 (1997)

33. P. E. Potter, P. Szatmari, Earth Sci. Rev. 96, 279-295 (2009).

34. P. B. deMenocal, Science 331, 540-542 (2011).

\section{ACKNOWLEDGMENTS}

This research used samples and data collected through the Integrated Ocean Drilling Program (IODP). The research was partially supported through the CTM 2008-06399-C04/MAR, CTM 2012-39599-C03, CGL2011-26493, CTM2012-38248, IGCP-619, INQUA 1204, and FWF P25831-N29 Projects. The Continental Margins Research Group at Royal Holloway.

University of London, also contributed to the research. We thank
REPSOL and TGS-NOPEC (Tomlinson Geophysical Services Inc. and Norwegian Petroleum Exploration Consultants) Geophysical Company ASA for use of an unpublished seismic record. We thank N. Khélifi (Springer, Germany) and M. Rogerson (University of Hull, UK) for discussing the changes in MOW density during the Pliocene and Quaternary, as well as the anonymous reviewers whose suggestions improved the final version of our manuscript. Data available at http://doi.pangaea.de/10.1594/ PANGAEA.832885?format=html and at the IODP web page, http:// iodp.tamu.edu/scienceops/expeditions/mediterranean outflow.html.

\section{SUPPLEMENTARY MATERIALS}

www.sciencemag.org/content/344/6189/1244/suppl/DC1 Materials and Methods

Figs. S1 to S4

Table S1

References (35-61)

24 January 2014; accepted 8 May 2014

$10.1126 /$ science. 1251306

\section{Asynchronous therapy restores motor control by rewiring of the rat corticospinal tract after stroke}

\author{
A. S. Wahl, ${ }^{1,2 *}$ W. Omlor, ${ }^{2}$ J. C. Rubio, ${ }^{3}$ J. L. Chen, ${ }^{2}$ H. Zheng, ${ }^{3}$ A. Schröter, ${ }^{4}$ M. Gullo, ${ }^{1,2}$ \\ O. Weinmann, ${ }^{1,2}$ K. Kobayashi, ${ }^{5}$ F. Helmchen, ${ }^{2}$ B. Ommer, ${ }^{3}$ M. E. Schwab ${ }^{1,2 *}$
}

The brain exhibits limited capacity for spontaneous restoration of lost motor functions after stroke. Rehabilitation is the prevailing clinical approach to augment functional recovery, but the scientific basis is poorly understood. Here, we show nearly full recovery of skilled forelimb functions in rats with large strokes when a growth-promoting immunotherapy against a neurite growth-inhibitory protein was applied to boost the sprouting of new fibers, before stabilizing the newly formed circuits by intensive training. In contrast, early high-intensity training during the growth phase destroyed the effect and led to aberrant fiber patterns. Pharmacogenetic experiments identified a subset of corticospinal fibers originating in the intact half of the forebrain, side-switching in the spinal cord to newly innervate the impaired limb and restore skilled motor function.

S troke is a major cause of severe disability in the elderly population, and recovery after large strokes is limited $(1,2)$. Current strategies to improve long-term outcome in humans include mostly rehabilitative training and, in experimental models, electrical stimulation and pharmacological interventions (3). However, all of these treatment options have had only limited success thus far $(4,5)$. Here, we show that rehabilitative training, if preceded by a nerve growth-promoting antibody therapy, almost completely restored skilled

\footnotetext{
${ }^{1}$ Department of Health Sciences and Technology, ETH Zurich, Zurich, Switzerland. ${ }^{2}$ Brain Research Institute, University of Zurich, Zurich, Switzerland. ${ }^{3}$ Computer Vision Group, Heidelberg Collaboratory for Image Processing and Interdisciplinary Center for Scientific Computing (IWR) University of Heidelberg, Heidelberg, Germany. ${ }^{4}$ Institute for Biomedical Engineering, ETH Zurich, Zurich, Switzerland. ${ }^{5}$ National Institute for Physiological Sciences, National Institute of Natural Sciences Myodaiji, Okazaki, Japan. *Corresponding author. E-mail: schwab@hifo.uzh.ch (M.E.S.); wah!@hifo.uzh.ch (A.S.W.)
}

forelimb functions after cortical strokes in adult rats. Sequential application of the treatments was essential: When growth promotion by blockade of the neurite growth-inhibitory protein Nogo-A was simultaneously applied with intensive forced-use training of the forelimb during the first 2 weeks after the stroke, functional outcome was poorer compared with training, immunotherapy alone, or no treatment at all (6). Anatomically, Nogo-A neutralization promoted growth of corticospinal fibers from the intact forebrain motor cortex across the midline of the cervical spinal cord. In rats with simultaneous antibody treatment and training, fiber branching was abundant with anatomically aberrant terminations. In contrast, in animals trained for forelimb function subsequent to antibody treatment, axonal fibers originally terminating in the intact spinal hemicord crossed the midline and innervated the ventral motor regions of the spinal hemicord that had lost its input from the motor cortex. To prove the functional relevance of these newly grown, "side-switched" descending corticospinal tract (CST) fibers, we selectively and temporarily blocked these fibers by two different pharmacogenetic techniques, both of which suppressed the restored forelimb function. Our results demonstrate that a sequential strategy of first promoting fiber growth to enhance the low endogenous plastic potential of the brain and spinal cord, followed by rehabilitative training-induced selection and stabilization of functionally meaningful connections can lead to much higher levels of functional restoration after the formation of large brain lesions than currently obtained in conventional rehabilitation medicine.

\section{Success of rehabilitation depends on timing}

We compared four different therapy and rehabilitation schedules for promoting functional recovery of fine motor skills of forelimbs in a thrombotic stroke model in rats. Using the wellestablished technique of photothrombosis (6), we induced blood vessel blockade by multiple microthrombi, which destroyed $>90 \%$ of the sensorymotor cortex of adult rats. Rats were then treated with intrathecal anti-Nogo-A or control antibody for 2 weeks $(6,7)$. In addition, we trained rats intensely in skilled forelimb reaching (100 reaches per day), either simultaneously with antibody application (parallel groups) or during the 2 weeks after antibody treatment (sequential groups) (Fig. 1A). To avoid a training effect of testing itself, we did not reassess the sequential groups (anti-Nogo-A/sequential and control sequential) during the first 2 weeks after lesion formation. When the growth-enhancing anti-Nogo-A treatment was followed by the rehabilitative training (anti-Nogo-A/sequential group), animals improved their performance from day 16 poststroke onwards, and their skilled reaching abilities almost completely recovered [reaching $86.3 \pm$ $2.0 \%$ of prestroke level; significantly better than all other groups; $P<0.001$, two-way repeated measures analysis of variance (ANOVA) with post hoc Bonferroni] (Fig. 1, A and B). This group also performed best in two skilled forelimb use tasks tested at the end of the experiment 
If you wish to distribute this article to others, you can order high-quality copies for your colleagues, clients, or customers by clicking here.

Permission to republish or repurpose articles or portions of articles can be obtained by following the guidelines here.

The following resources related to this article are available online at www.sciencemag.org (this information is current as of March 11, 2015 ):

Updated information and services, including high-resolution figures, can be found in the online version of this article at:

http://www.sciencemag.org/content/344/6189/1244.full.html

Supporting Online Material can be found at:

http://www.sciencemag.org/content/suppl/2014/06/11/344.6189.1244.DC1.html

A list of selected additional articles on the Science Web sites related to this article can be found at:

http://www.sciencemag.org/content/344/6189/1244.full.html\#related

This article cites 52 articles, 9 of which can be accessed free:

http://www.sciencemag.org/content/344/6189/1244.full.html\#ref-list-1

This article has been cited by 1 articles hosted by HighWire Press; see: http://www.sciencemag.org/content/344/6189/1244.full.html\#related-urls

This article appears in the following subject collections:

Oceanography

http://www.sciencemag.org/cgi/collection/oceans 